\title{
Chronic Uterine Inversion due to Myoma Geburt
}

\author{
Bobby Indra Utama* \\ Department of Obstetrics and Gynecology, Division of Urogynecolgy, RSUP Dr. M. Djamil, Padang, Indonesia
}

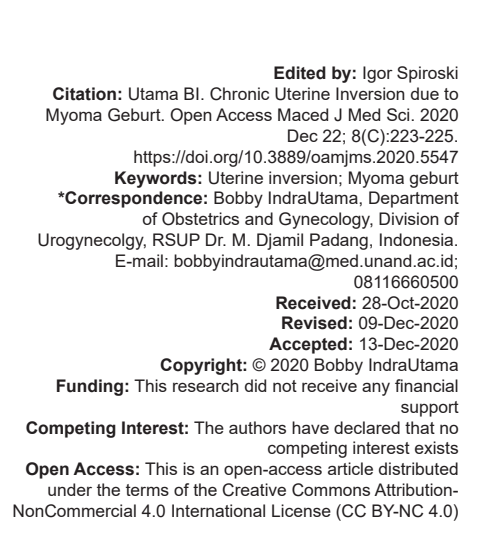

Abstract

BACKGROUND: Uterine inversion is a rare obstetric emergency but potentially serious complication of labor. This disease characterized by severe pain and can cause life-threatening condition. If these not immediately identified, the massive and underestimated blood loss can lead to hypovolemic shock. Therefore, early diagnosis and management of this condition is desirable. The objective of the study was to report on the management of chronic uterine inversion due to myoma geburt.

CASE REPORT: A 46-year-old patient was admitted to the gynecology ward of Dr. M. Djamil Central General Hospital with slight bleeding from vagina for 1 month ago with 2-3 pieces of underwear dark red colored, with pain. Bleeding from the vagina often recurs. There was a mass revealed from vagina with size as big as baby's head. The mass had pus and necrotic tissue.

CONCLUSION: Uterine inversion is a serious obstetric complication due to life threaten of the patient. Its low incidence leads to scarce experience in solving this kind of situation. There are some risk factors or mechanism as an underlying etiology of uterine inversion. The authors concluded that the presence of myoma geburt can be associated with the chronic uterine inversion. Surgical approach by eksterpation of myoma geburt with total hysterectomy can be the right procedure. Therefore, it is essential to keep in mind this diagnosis in all cases of vaginal bleeding.

\section{Introduction}

Uterine inversion is a rare obstetric emergency but potentially serious complication of labor. This disease characterized by severe pain and can cause lifethreatening condition. If these not immediately identified, the massive and underestimated blood loss can lead to hypovolemic shock. This condition includes of maternal death and reaches $15 \%$ in some series. Puerperal uterine inversion is a rare complication of mismanaged third stage of labor in which the uterus turns inside out through the cervix. Puerperal uterine inversion is more common than non-puerperal uterine inversion and its incidence varies from 1 in 2000 to 1 in 50,000 births. The most common etiology of uterine inversion is excessive umbilical cord traction with a fundal attachment of placenta and fundal pressure in the setting of a relaxed uterus. Another risk factors are rapid labor, uterine overdistension, invasive placentation, manual removal of placenta, short umbilical cord, use of uterine-relaxing agents, fetal macrosomia, nulliparity, placenta previa, connective tissue disorders, and history of uterine inversion in the previous pregnancy. However, this condition can be unpredictable due to no risk factors are identified. The diagnosis is based on clinical examination and must be identified quickly to avoid the formation of a constriction ring. Early diagnosed and treated will decrease the mortality rate. Reinversion should be quick followed by shock resuscitation management.
There are several therapeutic management including drugs and manual maneuvers described in the literature. The aim of this article is to describe a case of chronic uterine inversion due to myoma geburt [1], [2], [3].

\section{Case Report}

A 46-year-old patient was admitted to the gynecology ward of Dr. M. Djamil Central General Hospital on April 14, 2019, at 12:00 Am, sent from polyclinic. Slight bleeding from vagina since 1 month ago with 2-3 pieces of underwear dark red colored, with pain. Bleeding from the vagina often recurs. There was a mass revealed from vagina with size as big as baby's head. The mass had pus and necrotic tissue. One month ago, the patient had curettage, and the results of leomyoma were known (Figure 1).

History enlargement of abdomen had been felt for 1 year ago. There was no history of extreme decreasing body weight, trauma, and flour albus. The patient had menarche at 12 years old, with irregular cycle every month which last for about 4-5 days each cycle with the amount of 2-3 times pad changes/day without pain. The patient has two child, the youngest one was 24 years old. There was no contraceptive history. 


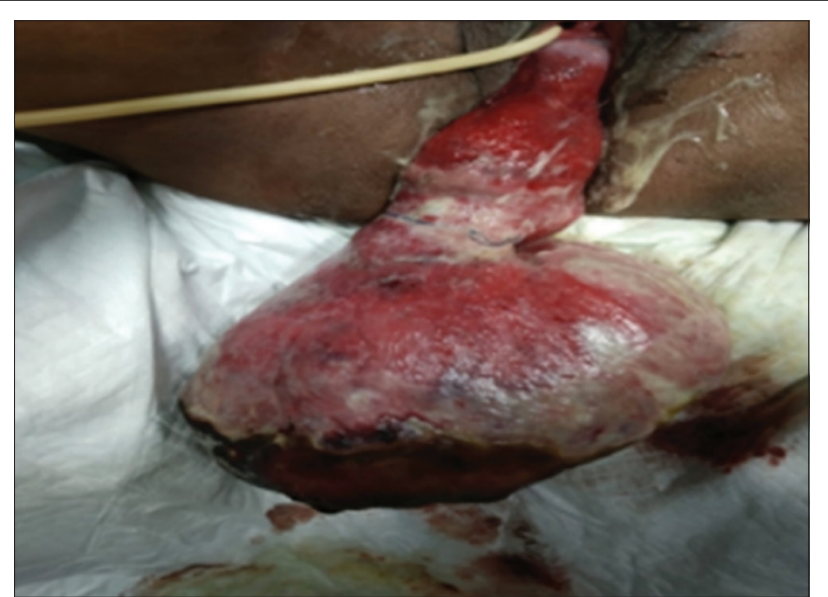

Figure 1: A mass revealed from vagina with size as big as baby's head. The mass had pus and necrotic tissue

There was no previous history of heart disease, liver disease, kidney disease, diabetic, hypertension, and allergy. From family illness history, there was no history of contagious disease, hereditary, and physiological illness in the family.

\section{Gynecology Record}

Inspection of V/U was normal. There was a mass revealed from vagina size as big as baby's head, pus $(+)$, necrotic tissue $(+)$, smells $(+)$, and PPV $(+)$ coming out from the vaginal opening, then portio cannot be evaluated. There were inversio uteri from vagina as big a duck egg. From the laboratory examination of the patient, they had hemoglobin $7.4 \mathrm{~g} / \mathrm{dl}$, leucocytes $25.570 / \mathrm{mm} 3$, platelets $679.000 / \mathrm{mm} 3$, hematocrit $24 / \mathrm{mm} 3$, prothrombin time $10.7 \mathrm{~s}$, activated partial thromboplastin time 34.9s, Blood glucose $112 \mathrm{~g} / \mathrm{dl}$, urea $43 \mathrm{mg} / \mathrm{dl}$, creatinine $0.8 \mathrm{mg} / \mathrm{dl}$, albumin $2.4 \mathrm{~g} / \mathrm{dl}$, globulin $3.9 \mathrm{~g} / \mathrm{dl}$, serum glutamic oxaloacetic transaminase $22 \mathrm{u} / \mathrm{l}$, serum glutamic pyruvic transaminase $25 \mathrm{u} / \mathrm{l}$, sodium 127 $\mathrm{Mmol} / \mathrm{L}$, potassium $3.9 \mathrm{Mmol} / \mathrm{L}$, chloride $103 \mathrm{Mmol} / \mathrm{L}$.

From anamnesis, physical examination, and laboratory examination, the patient was diagnosed with chronic uterine inversion due to myoma geburt + mild anemia + hypoalbuminemia. Management of the patient include of catheter urine, transfusion using packed red cells, and hypoalbuminemia correction with albumin $20 \%$. Then, operative management is eksterpasion of myoma geburt with total hysterectomy using Huntington technique surgery.

\section{Discussion}

Uterine inversion is defined as the uterine fundus turning to inside out through the endometrial cavity and cervix. The causes of uterine inversion still unexplained. Some risk factors associated with this situation are tension on the umbilical cord, fetal macrosomia, excessive fundal pressure, placenta accreta, short umbilical cord, ligaments laxity, and congenital abnormalities[4]. It is classified as $1^{\text {st }}$ degree if the fundus is inside the cavity. Then, as a $2^{\text {nd }}$ degree inversion when it reaches but does not exceed the cervical external os. A $3^{\text {rd }}$ degree inversion due to fundus extends out of the external os, and $4^{\text {th }}$ degree called as complete inversion beyond the vagina; introitus [5]. The uterine inversion can be diagnosed by clinical examination. A $4^{\text {th }}$ degree or complete inversion can be easily identified as the uterine fundus beyond the vaginal introitus. However, the diagnosis often be identified by the presence of massive blood loss after childbirth. Uterine fundus was absence in the abdominal palpation. These conditions associated with serious condition marked by hypotension and tachycardia. The patient could be evolved into hypovolemic shock. Although the certain etiology is still unknown, some mechanisms, such as thin uterine wall, coexistent and rapidly growing tumor, fundal tumoral location, tumor with a thin pedicle, and cervical dilatation, are condition associated to uterine inversion[6]. The most common tumor in benign group was myoma. In our case, the presence of the myoma geburt excised during the operation. These indicated the rapidly growing myomas as the etiological factor.

The management of these patients should be based on the underlying etiology. Our case might provide evidence to chronic uterine inversion due to myoma geburt. A chronic uterine inversion which might threaten the patients' life needs either manual reduction. In this case, we performed eksterpation of myoma geburt with total hysterectomy using Huntington technique surgery (Figure 2).

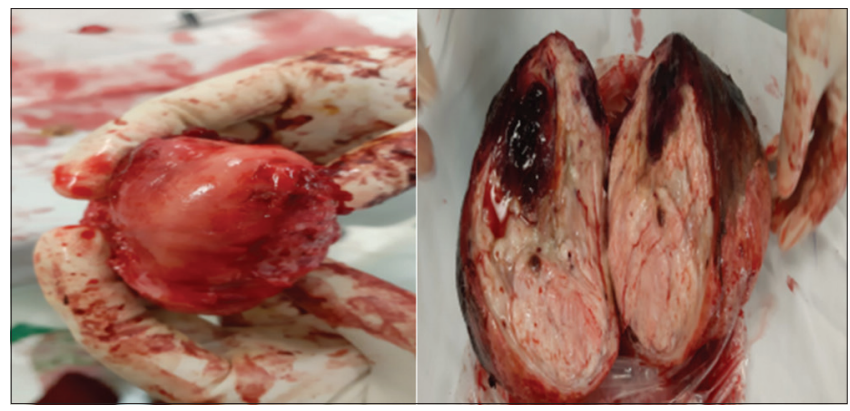

Figure 2: Myoma geburt

\section{Conclusion}

Uterine inversion is a serious obstetric complication due to life threaten of the patient. Rapid diagnosis and immediate clinical action are desirable. Its low incidence leads to scarce experience in solving this kind of situation. There are some risk factors or mechanism as an underlying etiology of uterine 
inversion. The authors concluded that the presence of myoma geburt can be associated with the chronic uterine inversion. Surgical approach by eksterpation of myoma geburt with total hysterectomy can be the right procedure. Therefore, it is essential to keep in mind this diagnosis in all cases of vaginal bleeding. Late diagnose and treatment of myoma causing serious complication.

Copy dan paste-kan tuliskan sumber dana (hibah) atau dukungan finansial lainnya disertai nomor hibah dan URL dari website penyandang dana (jika ada).

\section{References}

1. Eddaoudi C, Grohs MA, Filali A.Uterine inversion: About a case.Pan Afr Med J.2018;29:99.https://doi.org/10.11604/ pamj.2018.29.99.13644

\section{PMid:29875980}

2. Rui Filipe ML,Luz RM, de Almeida JP,Duarte V,Matos I.Total and acute uterine inversion after delivery: A case report. J Med Case Rep. 2014;8:347.

PMid:25326075

3. Dwivedi S, Gupta N, Mishra A, Pande S, Lal P. Uterine inversion: A shocking aftermath of mismanaged third stage of labour. Int $\mathrm{J}$ ReprodContraceptObstet Gynecol. 2013;2(3):292-5.https://doi. org/10.5455/2320-1770.jircog20130907

4. Witteveen T, Van Stralen G, Zwart J, Van Roosmalen J. Puerperal uterine inversion in the Netherlands: A nationwide cohort study. ActaObstetGynecol Scand. 2013;92(3):334 https://doi.org/10.1111/j.1600-0412.2012.01514.x PMid:22881867

5. Pauleta R, Rodrigues R, Melo A, Graça L. Ultrasonographic diagnosis of incomplete uterine inversion. Ultrasound Obstet Gynecol. 2010;36(2):260.https://doi.org/10.1002/uog.7735 PMid:20597092

6. Lascarides $\mathrm{E}$, Cohen M. Surgical management of nonpuerperal inversion of the uterus. Obstet Gynecol. 1968;32(3):376-81. PMid:5754584 